\title{
The origin of cycle life degradation of a lead-acid battery under constant voltage charging
}

\author{
Arif Hariyadi, Awan Nugroho, Suwarno \\ Department of Mechanical Engineering, Institut Teknologi Sepuluh Nopember (ITS), Surabaya, Indonesia
}

\begin{tabular}{l} 
Article Info \\
\hline Article history: \\
Received Sep 23, 2020 \\
Revised Feb 19, 2021 \\
Accepted Mar 6, 2021 \\
\hline
\end{tabular}

\section{Keywords:}

Battery

Degradation capacity

Lead-acid battery

Sulfation

Voltage

\begin{abstract}
Due to its low cost and recycle-ability, the lead-acid battery is widely used in mobile and stationary applications. Despite much research on lead-acid batteries, the effect of charging voltage on the degradation mechanism requires further investigation. In particular, the origin of cycle life degradation remains unclear. In the present work, by using electrochemical tests and materials characterization, we studied the effect of charging voltage at voltages slightly higher than the open-circuit potential (OCP) i.e., 103$107 \%$ OCP, on the battery life cycle. The highest degradation was observed at $105 \%$ OCP charging voltage. Based on the materials characterization results, we found that the degradation of a lead-acid battery is influenced by the amount of hard sulfate and the sulfate particles' size.
\end{abstract}

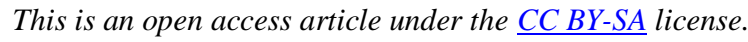

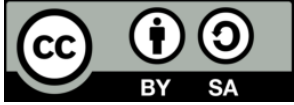

\section{Corresponding Author:}

Suwarno

Department of Mechanical Engineering

Institut Teknologi Sepuluh Nopember (ITS)

Kampus ITS Keputih Sukolilo Surabaya

Email:warno@me.its.ac.id

\section{INTRODUCTION}

The development of renewable energy is one of the factors in the growing global demand for energy storage. The share of renewable energy is expected to rise from $25 \%$ in 2015 to $85 \%$ in 2050, with the highest predicted proportion generated by wind power and photovoltaic (PV) sources [1]. Wind and solar power sources are intermittent energy sources. This intermittent energy production has to be stabilized using either energy from the grid (for an interconnected power plant) or energy storage (for a stand-alone power system) [2], [3]. In combination with energy storage, e.g., a battery, a controller balances the power generation intermittency and the load dynamics [4]-[7].

A battery is an energy storage device that stores electrical energy in the form of chemical energy. The lead-acid battery is one of the most widely used rechargeable/secondary batteries. This battery type is well established for industrial applications (e.g., stationary units and start-stop in automobiles) and has been successfully applied to utility energy storage [8], [9]. Lead-acid batteries are widely used because of their low cost, reliability, simple manufacturing, and an established method for lead recycling [10]-[12].

The mode of charging and discharging depends on the application. For example, renewable energy storage requires the battery to be at a partial state of charge. In other instances, in automotive startinglighting-igniting, the battery primarily operates at a float charging. It is well-known that charge-discharge modes will cause different deterioration types, resulting in a variation in the battery's lifetime [13], [14]. The variety of lead-acid battery failure modes can be divided into three categories, i) positive active mass degradation and loss of adherence, ii) sulfation of the active material, and iii) other factors, such as the 
electrolyte, separator, and charge-discharge regime [15], [16]. These aging mechanisms and failure modes of the lead-acid battery have been reviewed elsewhere [15]-[21].

Despite a large amount of research on the various modes of charging, the effect of charging voltage on the battery failure mode (particularly the relationship between the charging voltage and their impact on battery degradation) requires further investigation. The present work involves analyzing the effect of the charging voltage at slightly above open-circuit potential (OCP) on the cycle life and the material degradation. We mostly focus on the materials characterization aspect to better understand the degradation process.

\section{RESEARCH METHOD}

In this study, a modified battery taken from a commercial VRLA (valve regulated lead acid) battery consisting of six cells with a capacity of $12 \mathrm{~V}-3.5 \mathrm{Ah}$ was used. The experimental setup preparation was performed by removing the third and fourth cells. Thus, each battery was converted into two batteries containing two cells each (4V-1.17Ah capacity) to match the potentiostat's capability. A metrohm autolab PGSTAT302N having $\pm 10 \mathrm{~V}$ voltage range was used to perform charging and discharging (electrochemical test). Figure 1 shows the electrochemical test scheme and setup using the experiment. The test was carried out with the chrono charge-discharge potentiostatic method.

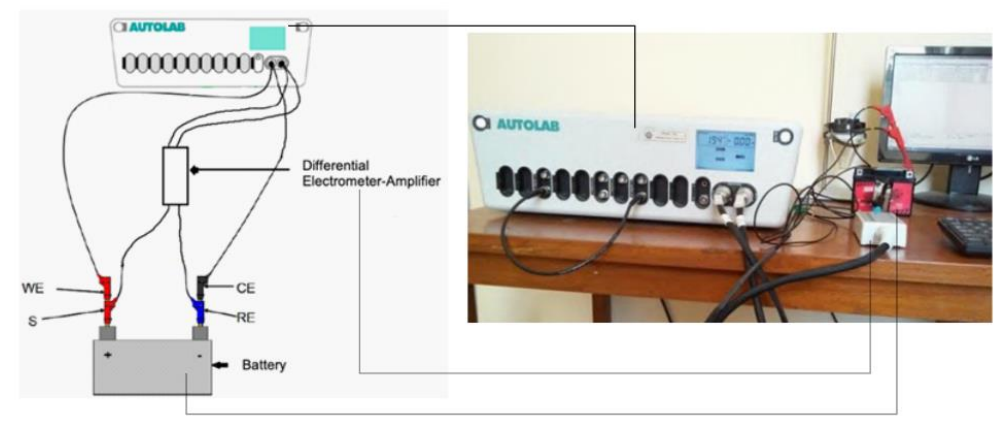

Figure 1. Schematic of the electrochemical test setup using metrohm autolab potentiostat in two electrodes set up, $\mathrm{RE}=$ reference electrode, $\mathrm{WE}=$ working electrode, and $\mathrm{S}=$ signal (left). The real experimental setup during the battery charging and discharging process (right)

Table 1. The tested samples and condition for charged and discharged

\begin{tabular}{ccc}
\hline Sample & Charge (\%OCP) & Discharge (\%OCP) \\
\hline 1 & 103,3 & 97,3 \\
2 & 105,3 & 97,3 \\
3 & 107,3 & 97,3 \\
\hline
\end{tabular}

Table 1 shows the list of tested samples and the condition for experiments. The charging voltage of the lead-acid battery depends on the application and can be higher than the open-circuit voltage. The OCP or open-circuit voltage of a measured lead-acid battery cell was used as a charging-discharging reference [22][24]. A potential of $4.28 \mathrm{~V}$ was achieved during the OCP measurements. All samples were discharged at a set voltage of $97.3 \%$ OCP. The first, second, and third samples were charged using different voltages of $103.3 \%$ OCP, $105.3 \%$ OCP, and 107.3\% OCP. The charge-discharge process was carried out for 40 cycles, and each charging/discharging time was set for 3600 seconds. An example of the charge and discharge process is shown in Figure 2. The discharge capacity $\left(\mathrm{C}_{\mathrm{d}}\right)$ of the samples was obtained by integrating the discharge current (I) with respect to time (t), as shown in (1) [25].

$$
C_{d}=\int_{t 1}^{t 2} I d t
$$

$\mathrm{X}$-ray diffraction (XRD) analysis was performed to investigate the new phase formed on the negative and positive electrodes of samples examined during the electrochemical tests. The XRD data were collected using an X-ray diffractometer PANalytical X'pert PRO with a $\mathrm{Cu}-\mathrm{K} \alpha$ radiation source. The morphological changes due to the new phase formed on the negative and positive electrodes were characterized using a CARL ZEISS EVO MA10 scanning electron microscope (SEM). The SEM was used to

The origin of cycle life degradation of a lead-acid battery under constant voltage charging (Arif Hariyadi) 
evaluate the surface characteristics, including the particle size distribution, of both the positive and negative electrodes [20], [26]-[31].

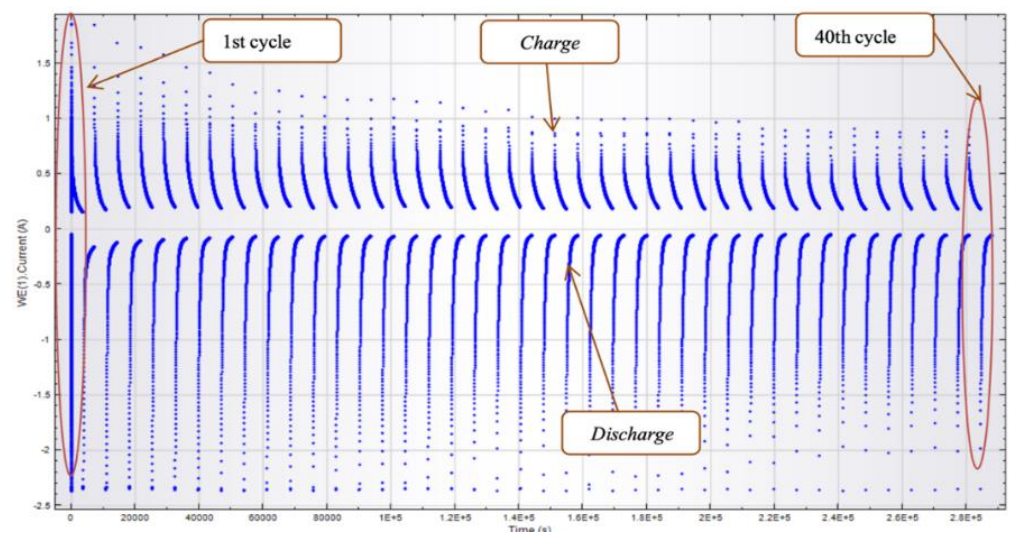

Figure 2. The example of the charge and discharge curves during the constant voltage charging

\section{RESULTS AND DISCUSSION}

\subsection{Electrochemical test}

Figure 3 shows the degradation of the discharge capacity of a battery throughout the cycle of the electrochemical test. The percentage of capacity degradation is calculated from the difference between the maximum capacity at the $1^{\text {st }}$ cycle and the latest cycle. The degradation of capacity from the highest to the lowest is $33.84 \%, 32.98 \%$, and $24.96 \%$ is observed from the sample at charging voltage of $105.3 \%$ OCP, $103.3 \%$ OCP, $107.3 \%$ OCP, respectively.

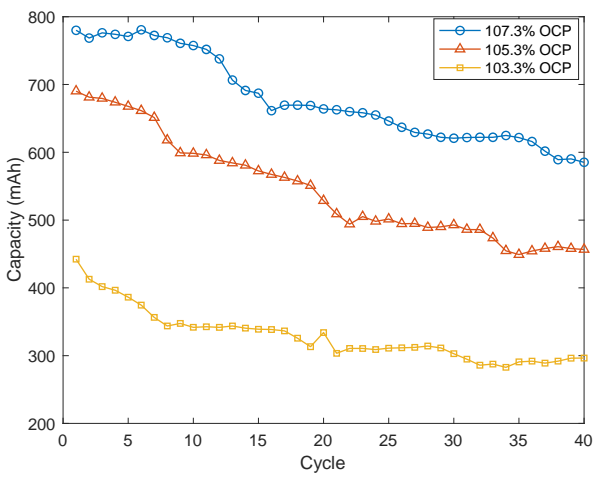

Figure 3. Degradation of capacity throughout the cycle after charging at different constant voltages (as shown in the legend). A cycle consists of charging and discharging

\subsection{Phase structural characterization}

To gain further insight into the degradation mechanism, XRD patterns of the samples before and after the electrochemical test are shown in Figure 4 for the positive electrode and in Figure 5 for the negative electrode. The XRD spectrum in Figure 4 (a) reveals that the original positive active materials were welldefined $\mathrm{PbO}_{2}$ crystals. Upon cycling, $\mathrm{PbSO}_{4}$ formation occurred; the $\mathrm{PbSO}_{4}$ was stable upon cycling. According to the XRD spectra $\mathrm{b}$ to $\mathrm{c}$ shown in Figure 4, the fraction of $\mathrm{PbSO}_{4}$ increased. The sulfation in this positive electrode decreased because the charging voltage is high. According to Figure 5 (a), the active material is comprised of well-crystallized $\mathrm{Pb}$ for the negative electrode before the charging cycle. The sulfation also occurs upon cycling. Thus, sulfation was observed in both negative and positive active materials; this observation was also made in previous work [32]. 


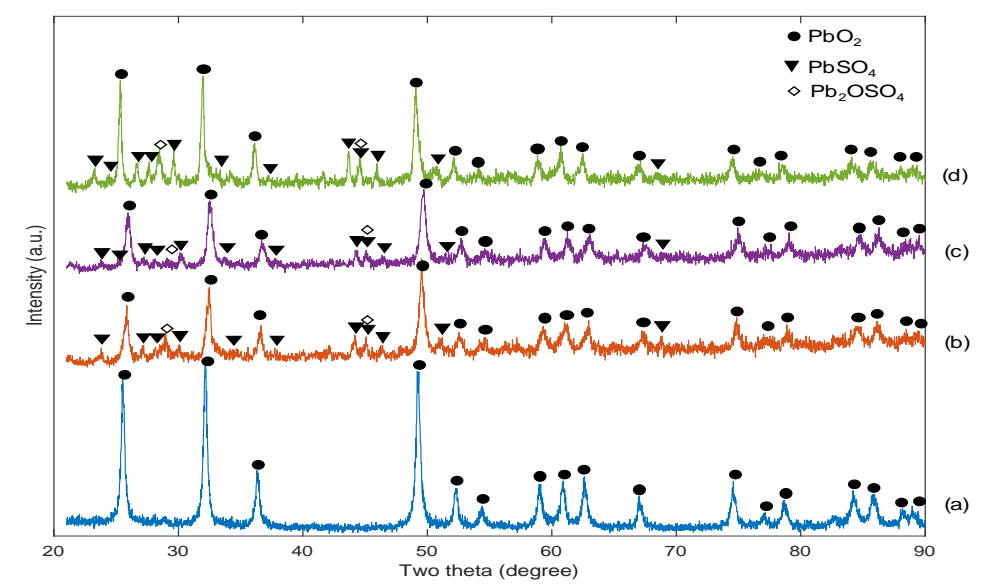

Figure 4. (a) XRD pattern of the positive electrode before the electrochemical test. XRD pattern of the positive electrode after 40 cycles of charging at; (b) $103.3 \%$ OCP, (c) $105.3 \%$ OCP, and (d) $107.3 \%$ OCP

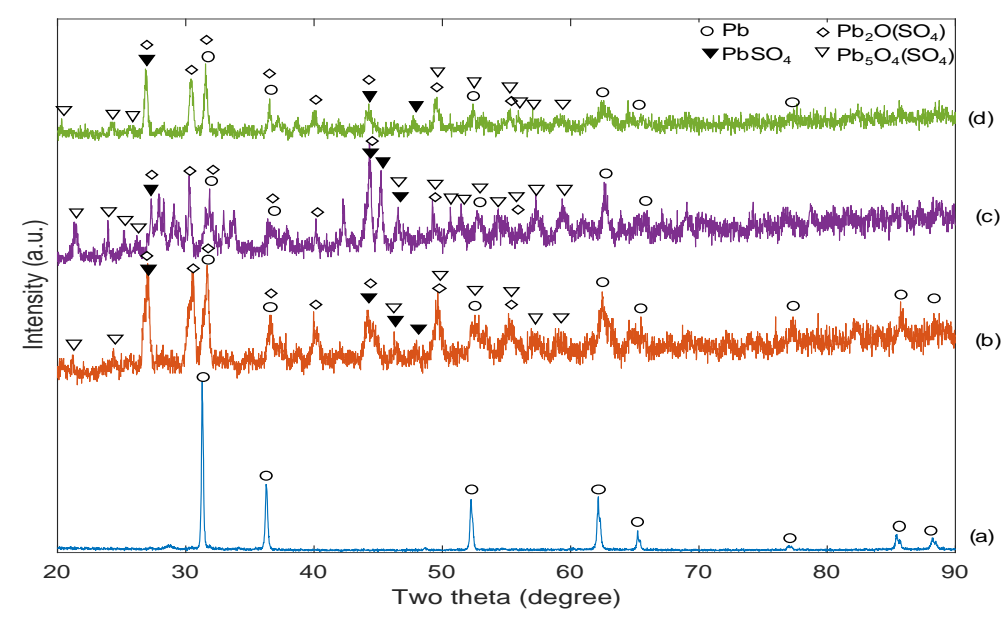

Figure 5. (a) XRD pattern on the negative electrode before the electrochemical test. XRD pattern on the negative electrode after 40 cycles of charging at; (b) $103.3 \%$ OCP charging, (c) $105.3 \%$ OCP charging, and (d) $107.3 \%$ OCP charging

\subsection{Microstructural characterization}

SEM analysis on the positive and negative active materials was conducted on the sample after cycling using a similar sample to that studied in the XRD analysis. The results of SEM image analysis on the discharged active materials are shown in Figure 6. It can be seen that, before the cycle test, the positive active materials consist of $\mathrm{PbO}_{2}$ crystal. After the cycling at different voltages, the sulfate particles start to appear, with the size being charging voltage dependence (Figure 6 (b) to Figure 6 (d). The SEM image for the negative active materials is shown in Figure 7. A similar trend was found; the higher the charge voltage, the smaller the lead sulfate formed. It can be seen that the lead sulfate formed on the negative electrode of the $103.3 \%$ OCP test tends to be small, and that of the $105.3 \%$ OCP test tends to be large. In contrast, at higher charging voltage, the sulfate particle becomes smaller. The lead sulfate, which does react back to pure $\mathrm{Pb}$, slowly converts into a stable crystalline form of sulfate that no longer dissolves on recharging. More crystalline lead sulfate in the active material reduces the reversible active phase, resulting in battery degradation. 


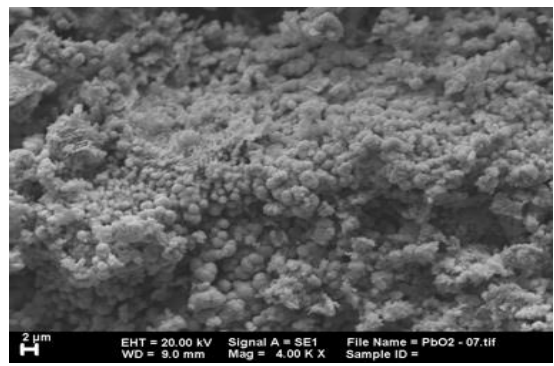

(a)

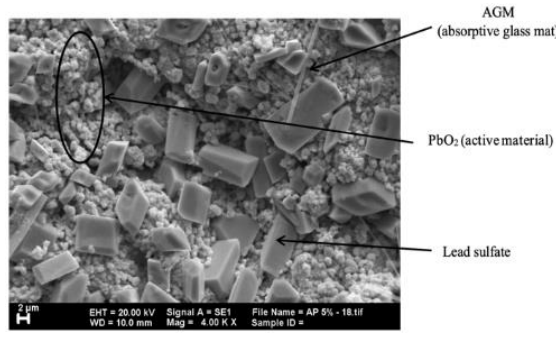

(c)

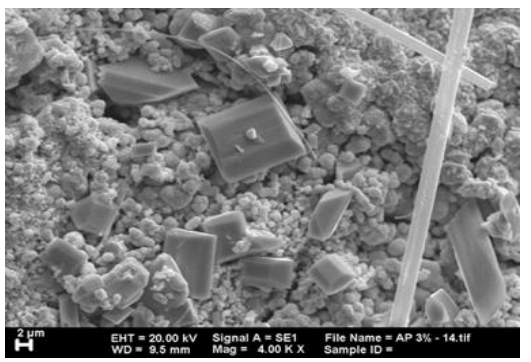

(b)

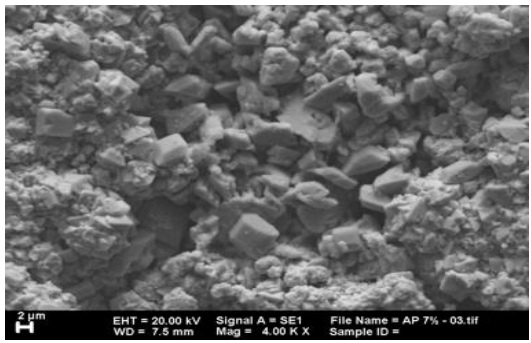

(d)

Figure 6. SEM micrographs with 4000 times magnification at the positive electrode, (a) before chargingdischarging, (b) $103.3 \%$ OCP, (c) $105.3 \%$ OCP, and (d) $107.3 \%$ OCP charging

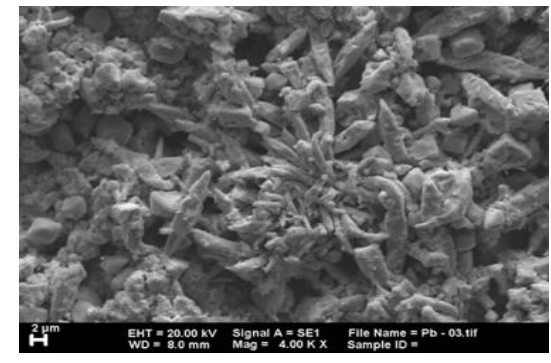

(a)

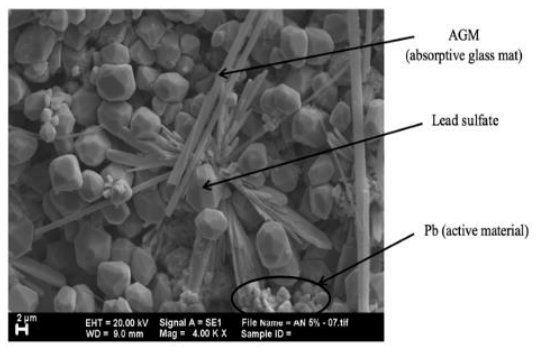

(c)

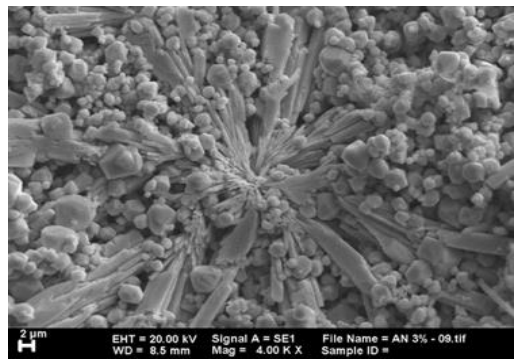

(b)

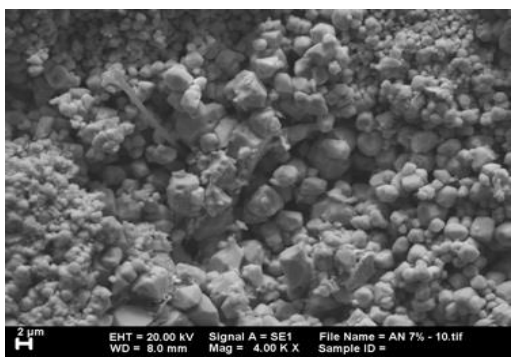

(d)

Figure 7. SEM micrographs with 4000 times magnification at the negative electrode, (a) before chargingdischarging, (b) $103.3 \%$ OCP, (c) $105.3 \%$ OCP, and (d) $107.3 \%$ OCP charging

The particle size can be measured statistically analyzed from an SEM image using linear intercept methods. The resulting plot of the particle size is shown in the Appendix. A direct comparison of the average particle size at each electrode is presented in Table 2. The table shows the lead sulfate average particle size before and after 40 times the charge and discharges cycling. The particle size at the positive and negative electrode was initially 0.353 and $0.655 \mu \mathrm{m}$, respectively. After the cycle test, the particle size increases to approximately $1 \mu \mathrm{m}$, with the size being dependent on the charging voltage. The smallest particle size for the cycled samples was observed for the battery that was charged at $107.3 \%$ OCP. The largest particle size was 
produced at the charging voltage of $105.3 \%$ OCP. The small particle size was found to be related to the high charging voltage that facilitates the dissolution of sulfate particles.

Table 2. The average particle sizes for lead sulfate

\begin{tabular}{ccccc}
\hline Variable & $\begin{array}{c}\text { before charging- } \\
\text { discharging }(\mu \mathrm{m})\end{array}$ & $\begin{array}{c}103.3 \% \text { OCP } \\
\text { charging }(\mu \mathrm{m})\end{array}$ & $\begin{array}{c}105.3 \% \text { OCP } \\
\text { charging }(\mu \mathrm{m})\end{array}$ & $\begin{array}{c}107.3 \% \text { OCP } \\
\text { charging }(\mu \mathrm{m})\end{array}$ \\
\hline Positive electrode & 0.353 & 0.960 & 1.283 & 0.891 \\
Negative electrode & 0.655 & 0.816 & 1.144 & 0.768 \\
\hline
\end{tabular}

\section{CONCLUSION}

Due to its scalable and mature manufacturing and recycling process, the lead-acid battery is widely applied in mobile and stationary applications. The charging voltage and scheme determine the cycle of the battery. It is commonly believed that the amount of stable sulfate particles causes lead-acid battery degradation. Based on the results of an electrochemical and materials characterization study, we showed direct evidence of sulfate particle size's influence on the degradation mechanism. The capacity degradation depends on the charging voltages, with the degradation after 40 cycles of $33.84 \%, 32.98 \%$, and $24.96 \%$ at the charging voltage of $105.3 \%$ OCP, $103.3 \%$ OCP, and $107.3 \%$ OCP, respectively. This degradation was found to originate from the size and amount of lead sulfate formed upon cycling. The phase fraction measurement confirmed this cause of degradation via XRD measurements and the particle size via SEM measurements. From those results, it can be concluded that degradation depends not only on the number of sulfate particles but also on the particles' size. The present work explains the sulfation process and should apply to many leadacid systems. Further research investigating various charging schemes related to the sulfate particle dissolution mechanism is required.

\section{ACKNOWLEDGMENTS}

Authors thank Departemen Teknik Mesin ITS for funding this present work through Skema Penelitian Mandiri Departemen year 2017.

\section{APPENDIX}

A1. Distributions of the lead sulfate particle size

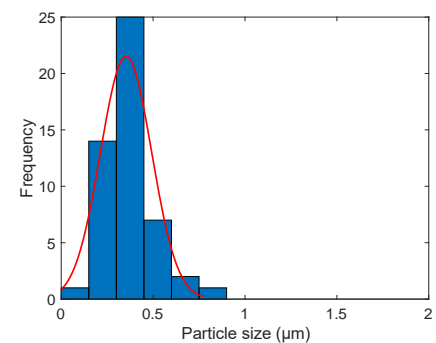

(a)

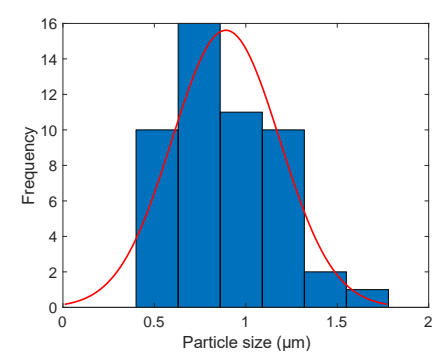

(d)

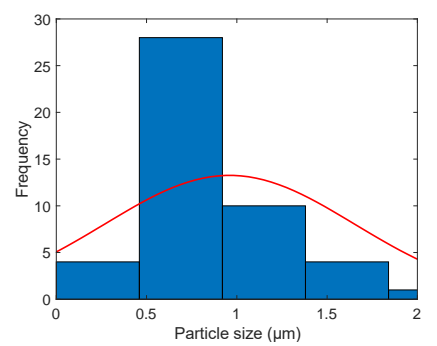

(b)

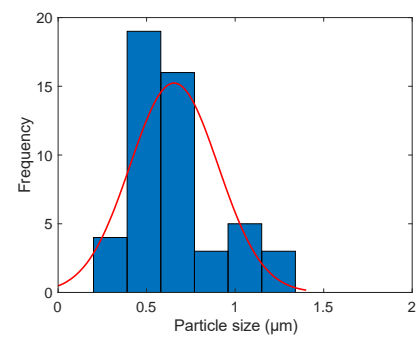

(e)

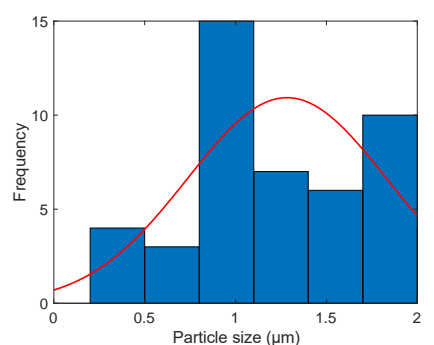

(c)

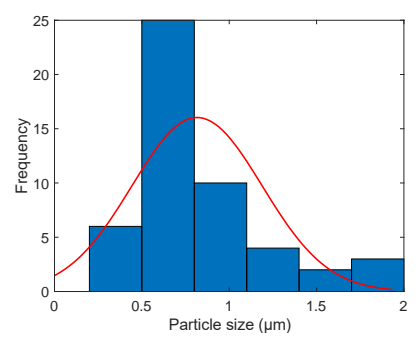

(f) 


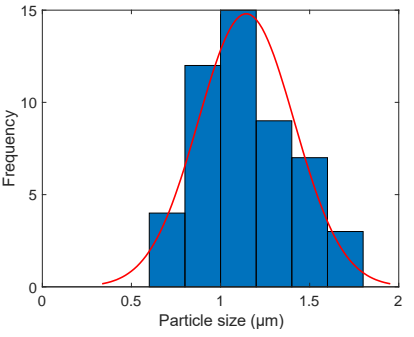

(g)

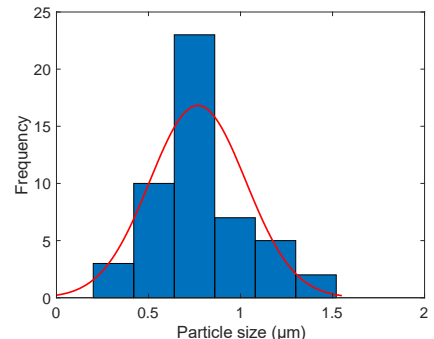

(h)

Figure A1. Distributions of the lead sulfate particle sizes

Positive electrode: (a) before testing, (b) $103.3 \%$ OCP, (c) $105.3 \%$ OCP, and (d) $107.3 \%$ OCP charging. Negative electrode: (e) before testing, (f) $103.3 \%$ OCP, (g) $105.3 \%$ OCP, and (h) $107.3 \%$ OCP charging.

\section{REFERENCES}

[1] D. Gielen, F. Boshell, D. Saygin, M. D. Bazilian, N. Wagner, and R. Gorini, "The role of renewable energy in the global energy transformation," Energy Strategy Reviews, vol. 24, pp. 38-50, 2019, DOI: 10.1016/j.esr.2019.01.006.

[2] M. Q. Taha, "Advantages and recent advances of smart energy grid," Bulletin of Electrical Engineering and Informatics, vol. 9, no. 5, pp. 1739-1746, 2020, DOI: 10.11591/eei.v9i5.2358.

[3] M. H. Amrollahi and S. M. T. Bathaee, "Techno-economic optimization of hybrid photovoltaic/wind generation together with energy storage system in a stand-alone micro-grid subjected to demand response," Applied Energy, vol. 202, pp. 66-77, 2017, DOI: 10.1016/j.apenergy.2017.05.116.

[4] I. Alhamrouni, F. Ramli, M. Salem, B. Ismail, A. Jusoh, and T. Sutikno, "Optimal power scheduling of renewable energy sources in micro-grid via distributed energy storage system," Telecommunication, Computing, Electronics and Control (Telkomnika), vol. 18, no. 4, pp. 2158-2168, 2020, DOI: 10.12928/telkomnika.v18i4.15159.

[5] Tinton Dwi Atmaja, Ant Ardath Kristi, Agus Risdiyanto, Bambang Susanto, Dian Andriani, Makoto Fujita, et al., "Fuel saving on diesel genset using PV/battery spike cutting in remote area microgrid," in MATEC Web of Conferences, 2018, vol. 164: EDP Sciences, p. 01045, DOI: 10.1051/matecconf/201816401045.

[6] D. Bozalakov, T. Vandoorn, B. Meersman, and L. Vandevelde, "Overview of increasing the penetration of renewable energy sources in the distribution grid by developing control strategies and using ancillary services," in IEEE Young Researchers Symposium, 2014: EESA.

[7] A. Khamis, M. R. Ab Ghani, G. C. Kim, M. S. M. Aras, M. A. B. Zabide, and T. Sutikno, "Control strategy for distributed integration of photovoltaic and battery energy storage system in micro-grids," Telecommunication, Computing, Electronics and Control (Telkomnika), vol. 16, no. 5, pp. 2415-2427, 2018, DOI: 10.12928/telkomnika.v16i5.10249.

[8] G. J. May, A. Davidson, and B. Monahov, "Lead batteries for utility energy storage: A review," Journal of Energy Storage, vol. 15, pp. 145-157, 2018/02/01/ 2018, DOI: 10.1016/j.est.2017.11.008.

[9] P. P. Lopes and V. R. Stamenkovic, "Past, present, and future of lead-acid batteries," Science, vol. 369, no. 6506, pp. 923-924, 2020, DOI: 10.1126/science.abd3352.

[10] H. Pourmirzaagha, V. Esfahanian, F. Sabetghadam, and F. Torabi, "Single and multi-objective optimization for the performance enhancement of lead-acid battery cell," International Journal of Energy Research, vol. 40, no. 14, pp. 1966-1978, 2016, DOI: 10.1002/er.3574.

[11] Zhi Sun, Hongbin Cao, Xihua Zhang, Xiao Lin, Wenwen Zheng, Guoqing Cao, et al., "Spent lead-acid battery recycling in China - A review and sustainable analyses on mass flow of lead," Waste Management, vol. 64, pp. 190-201, 017, DOI: 10.1016/j.wasman.2017.03.007.

[12] B. Rajanna and M. K. Kumar, "Dynamic model development for lead acid storage battery," Indonesian Journal of Electrical Engineering and Computer Science (IJEECS), vol. 15, no. 2, pp. 609-619, 2019, DOI: 10.11591/ijeecs.v15.i2.pp609-619.

[13] Y. Wong, W. G. Hurley, and W. H. Wölfle, "Charge regimes for valve-regulated lead-acid batteries: Performance overview inclusive of temperature compensation," Journal of Power Sources, vol. 183, no. 2, pp. 783-791, 2008, DOI: 10.1016/j.jpowsour.2008.05.069.

[14] K. Brik and F. ben Ammar, "Causal tree analysis of depth degradation of the lead acid battery," Journal of Power Sources, vol. 228, pp. 39-46,2013, DOI: 10.1016/j.jpowsour.2012.10.088.

[15] J. Yang, C. Hu, H. Wang, K. Yang, J. B. Liu, and H. Yan, "Review on the research of failure modes and mechanism for lead-acid batteries," International Journal of Energy Research, vol. 41, no. 3, pp. 336-352, 2017, DOI: 10.1002/er.3613.

[16] P. Ruetschi, "Aging mechanisms and service life of lead-acid batteries," Journal of Power Sources, vol. 127, no. 1, pp. 33-44, 2004/03/10/ 2004, DOI: 10.1016/j.jpowsour.2003.09.052.

[17] K. Nakamura, M. Shiomi, K. Takahashi, and M. Tsubota, "Failure modes of valve-regulated lead/acid batteries," Journal of Power Sources, vol. 59, no. 1, pp. 153-157, 1996, DOI: 10.1016/0378-7753(95)02317-8. 
[18] L. T. Lam, N. P. Haigh, C. G. Phyland, and A. J. Urban, "Failure mode of valve-regulated lead-acid batteries under high-rate partial-state-of-charge operation," Journal of Power Sources, vol. 133, no. 1, pp. 126-134, 2004, DOI: 10.1016/j.jpowsour.2003.11.048.

[19] J. H. Yan, W. S. Li, and Q. Y. Zhan, "Failure mechanism of valve-regulated lead-acid batteries under high-power cycling," Journal of Power Sources, vol. 133, no. 1, pp. 135-140, 2004, DOI: 10.1016/j.jpowsour.2003.11.075.

[20] Y. Guo, S. Tang, G. Meng, and S. Yang, "Failure modes of valve-regulated lead-acid batteries for electric bicycle applications in deep discharge," Journal of Power Sources, vol. 191, no. 1, pp. 127-133, 2009, DOI: 10.1016/j.jpowsour.2008.08.059.

[21] Y. Sun, H. Jou, and J. Wu, "Aging estimation method for lead-acid battery," IEEE Transactions on Energy Conversion, vol. 26, no. 1, pp. 264-271, 2011, DOI: 10.1109/TEC.2010.2040478.

[22] A. Qurthobi, A. B. K. Pambudi, D. Darmawan, and R. F. Iskandar, "Correlation between battery voltage under loaded condition and estimated state of charge at valve-regulated lead acid battery on discharge condition using open circuit voltage method," International Journal of Power Electronics and Drive Systems (IJPEDS), vol. 9, no. 1, p. 357, 2018, DOI: 10.11591/ijpeds.v9.i1.pp357-364.

[23] S. Lee, J. Cherry, M. Safoutin, and J. McDonald, "Modeling and validation of $12 \mathrm{~V}$ lead-acid battery for stop-start technology,” SAE Technical Paper, 0148-7191, 2017, DOI: 10.4271/2017-01-1211.

[24] M. Souaihia, B. Belmadani, and R. Taleb, "A robust state of charge estimation for multiple models of lead acid battery using adaptive extended Kalman filter,” Bulletin of Electrical Engineering and Informatics (BEEI), vol. 9, no. 1, pp. 1-11, 2020, DOI: 10.11591/eei.v9i1.1486.

[25] A. Kirchev, "Chapter 20 - battery management and battery diagnostics," in Electrochemical Energy Storage for Renewable Sources and Grid Balancing, P. T. Moseley and J. Garche Eds. Amsterdam: Elsevier, 2015, pp. 411435.

[26] C. Dai, T. Yi, D. Wang, and X. Hu, "Effects of lead-foam grids on performance of VRLA battery," Journal of Power Sources, vol. 158, no. 2, pp. 885-890, 2006, DOI: 10.1016/j.jpowsour.2005.11.047.

[27] J. Wang, H. K. Liu, S. X. Dou, S. Zhong, Y. Zhu, and C. Fu, "Enhanced performance of VRLA batteries with a novel spirally-wound electrode design," Journal of Power Sources, vol. 113, no. 2, pp. 241-244, 2003, DOI: 10.1016/S0378-7753(02)00519-0.

[28] V. Svoboda, H. Doering, and J. Garche, "The influence of fast charging on the performance of VRLA batteries," Journal of Power Sources, vol. 144, no. 1, pp. 244-254, 2005, DOI: 10.1016/j.jpowsour.2004.12.026.

[29] C.-S. Dai, B. Zhang, D.-L. Wang, T.-f. Yi, and X.-G. Hu, "Study of influence of lead foam as negative electrode current collector material on VRLA battery charge performance," Journal of Alloys and Compounds, vol. 422, no. 1, pp. 332-337, 2006, DOI: 10.1016/j.jallcom.2005.12.012.

[30] J. H. Yan, H. Y. Chen, W. S. Li, C. I. Wang, and Q. Y. Zhan, "A study on quick charging method for small VRLA batteries," Journal of Power Sources, vol. 158, no. 2, pp. 1047-1053, 2006, DOI: 10.1016/j.jpowsour.2005.11.016.

[31] Muhammad Ghufron, Kurriawan Budi Pranata, Istiroyah Istiroyah, Masruroh Masruroh, Cholisina Anik Perwita, and Ahmad A. Amirullah, "Electrode size influence on static and dynamic single cell lead-acid battery," Telecommunication, Computing, Electronics and Control (Telkomnika), vol. 17, no. 6, pp. 2919-2925, 2019, DOI: 10.12928/telkomnika.v17i6.11913.

[32] Suwarno, Witantyo, and Irawan, "Effect of depth of discharge on morphology and size of sulfate particles in VRLA battery electrodes," in AIP Conference Proceedings, 2018, vol. 1983, no. 1: AIP Publishing LLC, p. 050015, DOI: $10.1063 / 1.5046288$. 